\title{
Conversion Of Industrial Hall Buildings
}

\author{
PEŘINKOVÁ Martina ${ }^{1, a^{*}}$, TWRDÁ Markéta ${ }^{2, b}$, KOLARČÍKOVÁ Lenka ${ }^{3, c}$ \\ 1, 2, ${ }^{3}$ Faculty of Civil Engineering, Technical University of Ostrava, Ludvíka Podéště 1875/17, \\ 70833 Ostrava - Poruba, Czech Republic \\ a martina.perinkova@vsb.cz, ${ }^{b}$ marketa.twrda.st@vsb.cz, ${ }^{\mathrm{c}}$ lenka.kolarcikova@vsb.cz
}

Keywords: reconstruction, conversion, historical and industrial buildings, brownfield regeneration

\begin{abstract}
Ostrava as a post-industrial city has many brownfields, black fields and industrial areas. Brownfields are one of the most important problems, which today's cities have to solve. Regeneration of them and then reintegration back to the city organism are very time-consuming and expensive. Theme conversion of listed industrial hall buildings, the assessment made solutions, converting three historic buildings, the former power station. Looking at the history of the buildings, the technical condition before reconstruction. Using qualitative analysis used to evaluate the progress of our selected objects. Using the principles of similar objects in other post-industrial cities and their historic buildings.
\end{abstract}

\section{Introduction}

The former industrial area Trojhalí is located in the former coking plant Karolina near the centre of the city of Ostrava. Trojhalí includes two indoor type objects, the former electric switchboard and a power plant Karolina. The set of buildings is a unique industrial monument, describing the prosperity and strength of the great industrial complex. " The complex covers an area of about 60 hectares. This is a large, predominantly free terrain, which was created by demolition of the industrial complex. The industrial activity of the area was finally terminated in 1985-1986. When disposing of the objects only the aboveground parts of the buildings were removed. The foundations and underground spaces as well as a variety of sumps with residual fillings were largely left under the surface of the ground. " [1]

\section{The history of the objects}

The power plant Karolina was built in 1905. It is a single-nave rectangular hall with a gable roof with a central risalit and a steel truss. The building is of a representative character of an architectural composition with the axial articulation of facades, brick filling lizens, plaster surfaces and decorative colored glass blocks. The power plant was shut down in the 1980s together with the coking plant Karolina.

The energy exchange no. III is located behind the hall of the power plant. The monumental twonave hall was built later in the 1920s. It served as a blower into blast furnaces of Žofin smelter, where gas as a by-product of metallurgical production was used. The subtle steel riveted construction lined with bricks is based on a robust reinforced concrete retaining wall. On the front façades there are wide and narrow windows, placed symmetrically. The interspace between the naves contains pillars and there are skylights in the entire width of the mansard roof .

150 years of heavy industry operation caused massive large-scale contamination. "The situation changed in 1997 when the Government decided to provide a state subsidy for the decontamination of the territories of Karolina. Simultaneously, the operation of the blast furnace plant of Vítkovice ironworks was terminated. This led to the improvement of air quality and abolition of the sanitary protection zone. " [2]

Decontamination of the Karolina site ran until 2005, for almost 7 years. After that the territory was monitored for further 3 years. Finally the success of the rehabilitation was confirmed. The total 
volume of extracted earth reached $794085 \mathrm{~m}^{3}$. "This was also the first case of a successful conversion of such a large territory afflicted with such massive contamination to a qualitatively higher level of use. Quite a wide range of modern rehabilitation technology was used on the rehabilitation of the site. And it was complicated by the fact that the location was in a dense urban area."[1]

\section{Conversion of the halls}

The reconstruction of Trojhalí began in August 2012. Both buildings were being reconstructed at the same time. The original price of the reconstruction was CZK 330 million. The contract was won by a company with the entry investment of CZK 150 million. The project was carried out by Gemo Olomouc company according to a project documentation of the architect Josef Pleskot. The architect conceived the whole area as link between the historical centre of the city and the lower Vítkovice areas. The entrance corridors of the objects are directed to this axis and allow the visitors to go through. The building of Dvojhalí, the former energy exchange no. III., serves as a covered square, and the hall of the power plant Karolina was converted into a multifunctional sports centre with a bar. The buildings were cleaned of the additional construction work to its original state. The total usable area is $10500 \mathrm{~m}^{2}$.
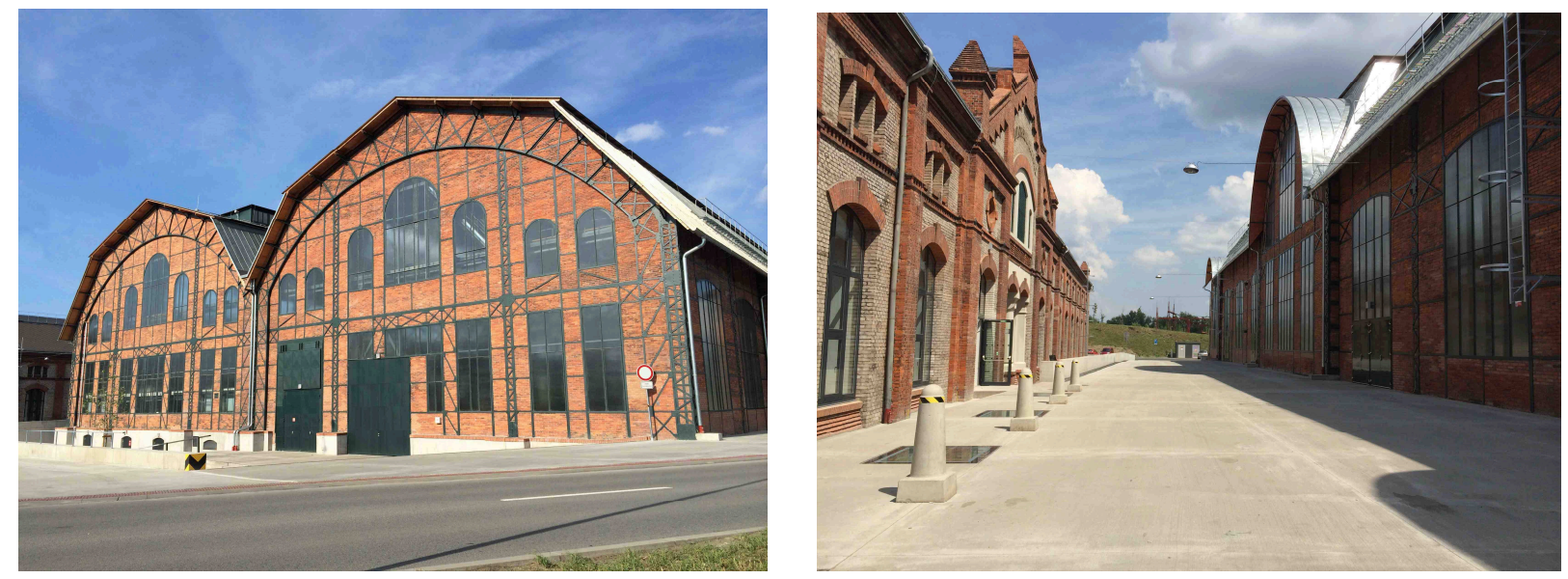

Fig. 1, 2 Trojhalí (photo: Lenka Kolarčíková)

The soil around the power plant building was removed up to the original level of the surface, with the intention to expose the ornate bases. Around the object, public space consisting of residential staircases and gallery was created. The cladding of the power plant is made up of white bricks in combination with roughcast brickwork. The bricks were chemically cleaned and impregnated with a hydrophobic substance. Damaged pieces were replaced with new ones. Due to the annual operation of the sports centre a new roof with thermal insulation was made. The existing windows were replaced with new aluminium ones. There was no need for heat insulation of the walls thanks to their sufficient width of approx. $90 \mathrm{~cm}$. The object is heated by hot water with heat exchanger station. The central part of risalits was newly plastered, including the columns and the existing stained glass was due to significant damage replaced by replicas using authentic technology- glass blowing.

Inside the hall there are two multi-purpose sports fields with sports floorboards. The walls were fitted with new plaster. In the middle of the layout a two-storey block with sanitary facilities for the physically disabled and a background for the buffet was inserted. The block is covered with large format square panels of enamel plates. Some of the painted pieces come from the art symposium named Enamel Art. 
Both objects were newly undermined and interconnected. As a result, a new basement area was created, which is now used as a communication node with a reception and sanitary facilities to both objects. Both objects are adapted to barrier-free use.

From the basement communication we can use a generously large ramp to get to the cathedral space of the two naves. According to the concept of a roofed square the inner space was restored to a simple construction with no specific function. The reconstruction was conceived with care. The damaged windows and skylights were replaced with the same type of fillings -armored glass. The floor as well as the new constructions of the gallery and entry ramps were made of cast concrete. The object is not heated, so there is no insulation or ventilation.

The supporting structure of the building consists of steel riveted framework, which is preserved in good condition. During the reconstruction the surface corrosion was removed by sandblasting. All steel elements were provided with high-quality anti-corrosion coating.

Before the project implementation, the redevelopment of the whole area of Karolina was considered, but it was discovered that the soil in the area was still very highly contaminated. It was necessary to excavate the contaminated soil and clean up the area. The project needed to consider the tilt of the buildings due to mining subsidence area. It required further costly measures to clean up the contaminated soil.
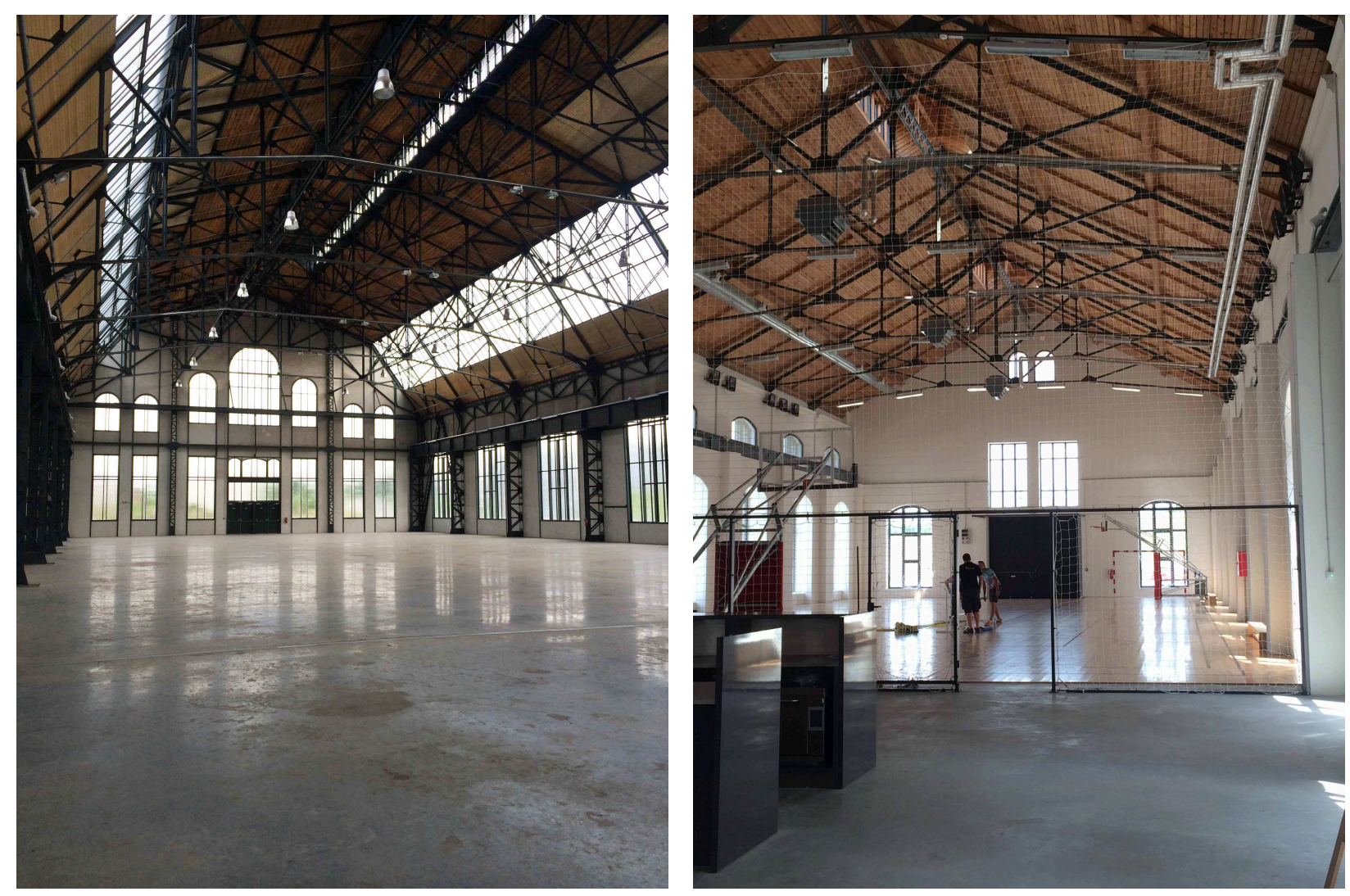

Fig. 3, 4.: Trojhalí (photo: Lenka Kolarčíková)

The project documentation was created at a time when the Karolina Shopping Centre with large underground garages was not yet built up. It was found out during the implementation that the construction of the shopping centre including the garages raised the groundwater level and there would be a danger of frequent flooding of the basement section. Because of this it was necessary to convert the basement floor construction from the classic foundation tank made of hydrophobic concretes to the white tank. The change of the base conditions made the construction more expensive by tens of millions.

The owners of the renovated area are: Trojhalí Karolina special-interest Association of legal entities, members of the Association Lower Vitkovice area, the statutory city of Ostrava, and the 
Moravian-Silesian region. $85 \%$ of the project was funded from EU fund for regional development and the rest of the funds was provided by the city of Ostrava. The total cost of the original 150 million increased to CZK 170 million due to the changes of the base conditions. A minimum of 812 people is needed to operate the building.

Between the buildings a street with glass skylights for illumination the basement corridor was created. The street forms a bridge between the historical centre and the lower Vitkovice area. Not only the solution of height levels but also ingenious insights highlight the value of this new public project.

\section{The Conclusion}

It is possible to use industrial objects of hall type if we find their new functionality. An architect supplements necessary technology and enables the re-use of historical buildings with new features. This can extend the period of use of the object.

"The conversion of historical buildings is usually a combination of several ways of working with the space and structures. The intention usually requires constructional- historical research clarifying the historically valuable construction and parts of the object, and then the study aims to fill the space with new features. " [3]

The conversion of Trojhalí with the transformation to the public space and sports facility will enable active use of the objects, which will extend their life to next 100 years at least. Make the conversion can be considered a prime example of saving industrial hall buildings in the Czech Republic. It is a decent preservation of an architectural monument from the peak of the industrial era in the Ostrava region for generations to come.

Many thanks to Mr. Ing. Petr Šnejdar for the provided information and the time devoted.

\section{References}

[1] V. Zamarský, J. Tylčer, T. Střelec, Z. Kaláb, P. Martinec, H. Paclová and R. Walica, Regenerace průmyslových ploch, II. díl. 1. vyd. Ostrava: VŠB-TECHNICKÁ UNIVERZITA OSTRAVA, 2011. ISBN 222-0941/02.

[2] V. Kuta, F. Kuda, Karolina - součást městského centra Ostravy. In: Sborník vědeckých prací Vysoké školy báňské - Technické univerzity Ostrava. Řada stavební 2003, roč. 3, č. 1, s. 99102. ISSN 1213-1962.

[3] M. Peřinková a kol. Současné formy užívání industriálních historických objektů. Praha: Gasset, 2012. ISBN 978-80-87079-25-6, pp. 133 